\section{Subsidiary strategy and managers' perceptions of distance to foreign markets}

Distance to foreign markets

\author{
Isabel Cristina Martins Antunes
}

Department of International Management, ISCAP, The Porto Accounting and Business School, Polytechnic of Porto, Porto, Portugal, and

Hortênsia Gouveia Barandas and Francisco Vitorino Martins Department of Management, School of Economics and Management, University of Porto, Porto, Portugal
Received 20 January 2019 Revised 3 June 2019 13 September 2019 Accepted 13 October 2019

\begin{abstract}
Purpose - The purpose of this paper is to examine how headquarters' managers perceive - cultural, administrative, geographic and economic (CAGE) - distance between countries and its influence on the strategy of international subsidiaries.

Design/methodology/approach - This study applies the transaction cost and behavioural theory and presents an exploratory and qualitative methodology approach through six semi-structured in-depth interviews to evaluate managers' perceptions of distance between countries.

Findings - The research findings show that cultural and economic distances indeed have a major influence on subsidiary strategy and a smaller impact of administrative and geographic dimensions, which results into forced changes on the marketing-mix, i.e. product, price, design and brand, as well as on the level of autonomy granted to foreign subsidiaries.
\end{abstract}

Research limitations/implications - The limitation is related to the home country and the entry mode of foreign direct investment. The findings presented here reflect the nature and behaviour of Portuguese companies with subsidiaries.

Practical implications - The research provides recommendations for managers to be aware of the influence of more than one dimension of distance between countries to improve their decision-making of standardisation-adaptation strategy for foreign subsidiaries. Furthermore, the study stresses that managers' perceptions may lead to the conclusion that proximity and knowledge of foreign markets does not make international business easier.

Originality/value - This empirical research not only tests the transaction cost theory and behavioural theory on managers' decisions to invest abroad but also promotes organisational changes to achieve the suitable strategy for international subsidiaries. The study contributes to the area of international business by positing six research propositions concerning distance between countries to be tested in future studies.

Keywords Case study, Foreign markets, Cultural administrative geographic economic distances, Managers' perceptions, Subsidiary strategy

Paper type Case study

\section{Introduction}

When companies invest abroad, they are involved in a managerial process where risk, opportunities and commitment must be evaluated. Researchers argue that there are differences between and within countries, regions and societies (Berry et al., 2010; Ghemawat, 2001, 2007; Rugman and Verbeke, 2004), which in terms of business management involves the development of strategies to meet these differences. According to

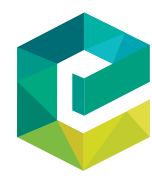

Review of International Business and Strategy

Vol. 29 No. 4, 2019 (1. 317.36

Emerald Publishing Limited 2059-6014 DOI 10.1108/RIBS-01-2019-0007 
RIBS

29,4

these authors, knowledge of (and commitment to) the local context is a key success factor for international business. In companies' internationalisation processes, the decisions are mostly made in terms of economic or behavioural lenses. The economic perspective is associated with the exploitation of an existing advantage. Alternatively, the behavioural perspective is based on behavioural matters (the attitudes, perceptions and behaviour of the actors involved). Driven by knowledge-based decisions, this approach is linked to the incremental internationalisation process of the firm, as proposed by the Uppsala school (Johanson and Vahlne, 1977; Johanson and Weidersheim-Paul, 1975) and extended by Nordstrom and Vahlne (1994), where a firm goes from exportation (low-commitment modes) to implementation a subsidiary abroad (high-commitment modes) and from local market to neighbouring countries before developing in 'psychically' distant countries.

The behavioural approach assumes that managers' decisions are based on their knowledge of the foreign markets (Ambos and Ambos, 2009; Gulanowski et al., 2018), and perceptions (Dow and Karunaratna, 2006; Ellis, 2008; Evans and Mavondo, 2002), especially when coupled with the psychic distance (PD) construct. Therefore, firms do not risk entering into a distant market before having both knowledge and experience in that market. In this view, psychically close countries are expected to be similar; therefore, few national differences and low uncertainty in terms of the foreign market promote successful internationalisation efforts.

The multidimensional nature of distance factors between countries and the importance of non-geographic barriers have been particularly emphasised in international business (IB) studies. Empirical work in this field has extensively used dimensions of national culture as a key dimension of distance. A few studies, however, have argued that these measures do not capture various social, political and economic diversities across countries that influence cross-border transactions. These works have increasingly emphasised differences in languages, religion, attitudes, legal systems, levels of industrial development, regulatory and trade regimes and travel and living as key inhibiting factors to international trade exchanges and foreign direct investment (FDI) (Berry et al., 2010; Dow and Karunaratna, 2006; Evans and Mavondo, 2002; Ghemawat, 2001).

According to previous studies of Ghemawat (2001) and Hutzschenreuter et al. (2016), distance between countries could initiate from both geographic separations and from administrative or political, economic and culture. Similar to the investigation of Kuo and Fang (2009), we believe that the four points of view: cultural, administrative, geographical and economic (CAGE) framework (Ghemawat, 2001) possesses additional explanatory power to empirically assess the distance between countries belonging to different regions.

Moreover, recent research calls for using perceptual data in assessing distance, primarily based on the argument that managers formulate strategies for responding to environmental demands based on their perceptions of a firm's external environment (Baack et al., 2015). Similarly, Maitland and Sammartino (2015) reports that our knowledge about how managers assess foreign environments is very limited and warrants further research.

The values and norms that underlie business practices may conflict with the beliefs that are embedded in the local markets, and thus sharing best practices globally could potentially be problematic if they conflict with different national environments. While the best practices might be shared, they also might provoke local conflicts.

Although previous studies incorporate perceptual measures of distance to explain internationalisation decisions (Azar, 2014; Drogendijk and Slangen, 2006; Häkanson et al., 2016), no research so far has investigated the managers' perceptions of psychic distance between countries and its implications in the subsidiary strategy related to organisational 
variables because of its assessment to the evaluation of the tradeoff between global integration and local responsiveness.

This study fills this gap and this research purposes to examine how the managers' perceptions of psychic distance between foreign country and home country affects subsidiaries' strategy.

This study contributes to IB research by empirically examining through six case studies the influence of the psychic CAGE distance framework on managers' perceptions of distance between home - host countries, as well as its implications on subsidiary strategy. From a managerial perspective, this study provides recommendations for managers to be aware of the influence of more than one dimension of distance between countries to better make their decisions of standardisation-adaptation on foreign markets.

The present findings validate perceptual data regarding the psychic distance, i.e. CAGE framework, to better respond to market demands. This refinement of distances brings new critical knowledge to decision-makers in international markets.

To analyse how the managers' perceptions of CAGE distance framework influences the business subsidiaries' strategy, this qualitative research applies a case study approach. Qualitative research substantially contributes to theoretical building on the functioning of international companies (Piekkari et al., 2009). Qualitative methods have a critical role in interpreting and understanding the plurality of contexts (namely, institutional, cultural and organisational), and the links between these contexts and companies that establish business relations beyond national borders (Birkinshaw et al., 2011; Doz, 2011).

To achieve our goal, this paper is structured in four parts. First, we submit the theoretical framework used in our research. Second, we present a methodological section providing details about the sample we selected, the questions and method of analysis. Third, we show the results of the formulated research questions. The fourth part concludes with propositions for future research.

\section{Literature review}

\section{Internationalisation process and the distance to foreign markets}

The concept of 'liability of foreignness' presents entrant firms to be disadvantaged in relation to local firms because of foreign exchange risks and unfamiliarity with the business conditions of the foreign market Hymer (1960). To overcome their liability of foreignness and to successfully compete against local firms, international firms must provide their overseas subsidiaries with certain firm-specific advantages such as knowledge, trademarks or management skills (Buckley and Casson, 1976; Caves, 1982). The empirical studies by Zaheer and Mosakowski (1997), however, show that the liability of foreignness tends to decline over time as firms gain local market knowledge, which diminishes the costs of doing business in a foreign country. The manner in which entrant firms are able to diminish their liability of foreignness or their learning process after an establishment has not been the concern of internationalisation theorists, but of behavioural theorists.

Behaviour theory understands the internationalisation of the firm as a process; its premises are based on the generation of knowledge over time, going from low commitment modes - exportation, to the highest level of commitment - the establishment of subsidiaries after accessing information about other countries. This approach assumes that knowledge and perceptions change over time during the internationalisation process; therefore, perception is an important feature, especially when coupled with the psychic distance (PD) construct (Dow and Karunaratna, 2006; Ellis, 2008; Evans and Mavondo, 2002).

This research investigates the subsidiary strategy depending how managers perceive the distance between countries using the multidimensional framework, CAGE, which comprises 
RIBS 29,4

relevant dimensions of distance between countries: cultural, administrative, geographical and economic (Ghemawat, 2001).

Cultural distance refers to the attributes of a society that are primarily sustained by the interactions between people, and not by the state. The effects of different languages, ethnicities, religions and social norms are the most obvious examples of this type of distance.

Administrative distance includes the laws, policies and institutions that typically emerge from a political process and are established or strengthened by governments. International relations between countries in terms of treaties and international organisations, as well as political or administrative attributes, such as colonial ties, membership in the same regional trading blocs and the use of a common currency, are examples that reduce this type of distance.

Geographical distance embodies physical distance, differences in time zones and differences in climate, topography, accessibility and communication infrastructures. The most immediate impact of long distances is the increasing cost of physical transport.

Economic distance evaluates the economic activities between countries and is affected by the countries' size, which increases the absolute amount of trade and reduces its percentage of gross domestic products (GDP). Other differences in production factors - such as cost or quality of natural resources, financial resources, human resources, infrastructures and information or knowledge - should also be examined for this type of distance.

Companies that engage in international relations need to take all these dimensions of distance into consideration for evaluating the target market and for more ably suiting their business strategies to their subsidiaries.

\section{Subsidiary strategy and managers' perceptions of distance between countries}

To overcome of the liabilities of foreignness, headquarters' companies choose the strategy that seems to be the most appropriate for the subsidiary in a specific country.

The MNC-subsidiary literature proposes three critical factors in developing organisational strategies: the MNC strategy, the subsidiary capabilities (skills and resources) and local environment.

The MNC strategy presents us with several typologies of strategy and organisation of the companies. As a result of the evaluation of the tradeoff between global integration and local responsiveness, Prahalad and Doz (1987) argued that multinational company adopts global, multidomestic or multifocal strategies. Following, Bartlett and Ghoshal (1989) and Ghoshal and Bartlett (1990) add the notion of the transnational strategy to simultaneously achieve global integration, national responsiveness and worldwide innovation. Adopting global strategies, the company deals with international markets as one, and thus globally integrated subsidiaries tend to have low autonomy (Taggart and Hood, 1999). Adopting multidomestic strategies takes in account the particularities of each national market; therefore, the local market-oriented subsidiaries require a degree of flexibility and have greater autonomy (Martinez and Jarillo, 1991; Harzing, 2000). The transnational strategies are between global and multidomestic strategies, dealing with the market as a regional one.

The subsidiary capabilities (skills and resources) determine the competence of the foreign subsidiary in key value activities (e.g. production and marketing) that can be used in the local market. According to their capabilities they can take on different roles, as a participant in the MNC's strategy or as a dependent organisation within the MNC company (Raziq et al., 2019).

The local environment is a crucial factor affecting subsidiary strategy (Bartlett and Ghoshal, 1989). An international company operating across national markets must exploit 
its unique firm-specific advantages that are transferable across national boundaries. However, because the MNC is operating in multiple country locations, it must also be responsive to the demands imposed by local market and factor conditions. To Mudambi and Navarra (2002), legal systems, political and administrative relations and social norms tend not to be transferable across countries; therefore, companies must adapt their strategies to address these differences and to meet business-specific factors (Buckley et al., 2007).

The global integration strategy seems more adequable for market-seeking motivations to invest abroad to achieve economies of scale and economies of scope. The implementation of the integration strategy indicates that their subsidiaries rely on parent firm's specific advantages to compete with local competitors in foreign markets (Rugman and Verbeke, 2004). Once the strategy envolves responsiveness to local markets, there is strategic assetseeking motivations to invest abroad. In this case, foreign subsidiaries can develop or acquire new firm's specific advantages by accessing host countries-specific advantages (Wei and Nguyen, 2017).

Assuming the abovementioned arguments, we claim that the headquarters managers' perceptions of a particular national environment determines where to operate as well as the suitable strategy for its subsidiaries.

The subsidiary strategy depends on the decision-making that affects the management of the company.

From the literature, two research questions were raised:

RQ1. Which are the distance dimensions: cultural, administrative, geographical and economic between home and host countries that had an impact on the business strategy of the international subsidiary?

RQ2. How managers' perceptions of cultural, administrative, geographical and economic distances dimensions between home and host countries influence the business strategy of the international subsidiary?

To answer our questions, Figure 1 presents the research model.

\section{Method: Case study research}

The choice of methodology for conducting a qualitative case study is appropriate for this research because it is directed at the stages of exploration, classification and propositions development of the process of knowledge construction (Eisenhardt and Graebner, 2007).

The case studies adopt a methodological approach to adapt research when trying to understand, explore or describe events, as well as complex contexts in which many factors are simultaneously involved (Eisenhardt, 1989; Yin, 2009). Although case study results will not be used in predicting future behaviour, they do contribute in advancing a field's knowledge base by offering insights and illuminating meanings.
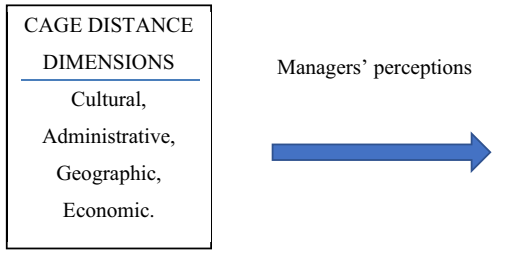

Distance to foreign markets

351 
RIBS

29,4

\section{Sample and data collection}

Our sample comprises six companies that have overseas investments in the form of subsidiaries. Our choice of six companies follows the criteria of the adopted methodology if one considers that five replications are required to improve reliability in complex case studies (Eisenhardt, 1989; Yin, 2009).

These six companies were selected as relevant because they show common features as well as differences relating to growth, innovation, reputation and recognition in the destination market.

The selected companies, operating in traditional industries, have leadership positions in their home market and high international recognition in foreign markets where they operate.

All the companies have international experience following the model of Uppsala, ranging from (low commitment to local context, exportation, to the highest level of commitment to foreign markets investing in a subsidiary.

In the data collection process, there was a concern to select companies with different location patterns in terms of the CAGE distance between countries.

To highlight cultural distance, the companies have subsidiaries in markets with different cultures according to Hofstede' s country scores (2003), particularly in power distance and masculinity/femininity criteria.

Administrative distance is also observed because some subsidiary companies are located in centralised economies (such as France and Italy), whereas others are in decentralised economies (such as Spain and Germany).

To observe the geographic distance, the sample has subsidiary companies that are not located in the geographic extension market, e.g. Spain.

The economic distance is perceived by comparing subsidiary companies located in emerging economies and in developed economies.

Their common aspects are identical positioning vis-à-vis competition in the home market, reputation in the foreign market and the fact that they chose FDI as a means of establishing their own subsidiaries. The distinctive aspects relate to differences in the sector of activity (Table I), international experience (from one to six different countries), age (1924 to the older company and 1977 to the most recent one), the type of foreign investment (through acquisition or greenfield investment) and the different host countries.

We should notice better the firm-specific advantages of the companies because they are important drivers of success in international markets and communicate their position in market. The company named 1 strives to attain an high market performance in the design of custom-made products for bathrooms, having become now a globally recognized brand in the construction sector. The company named 2 is a leader, with over than 90 years of experience in the paints and varnishes market. It is seen as a benchmark from the point of view of $R \& D$ in its sector. It dictates new trends in the markets where it operates. The company named 3 achieved the position of Iberian market leader in fruit preparations for the food industry by working in close partnership with its clients and suppliers to look for differentiated processes and products and trying to anticipate market trends. The company named 4 has one of the most unique tissue brands in the world because of its eagerness to take innovative risks and encourage change. The company's humorous and open-minded approach offers colourful designs and new functional solutions through stylish and environmentally friendly funny home and body products. The company named 5 is one of the main pharmaceutical companies in the Iberian Peninsula that provides high-quality medicines. The company encourages teamwork at all functional levels, because it believes in an ongoing training system that enables all human resources to be upgraded and upskilled. 


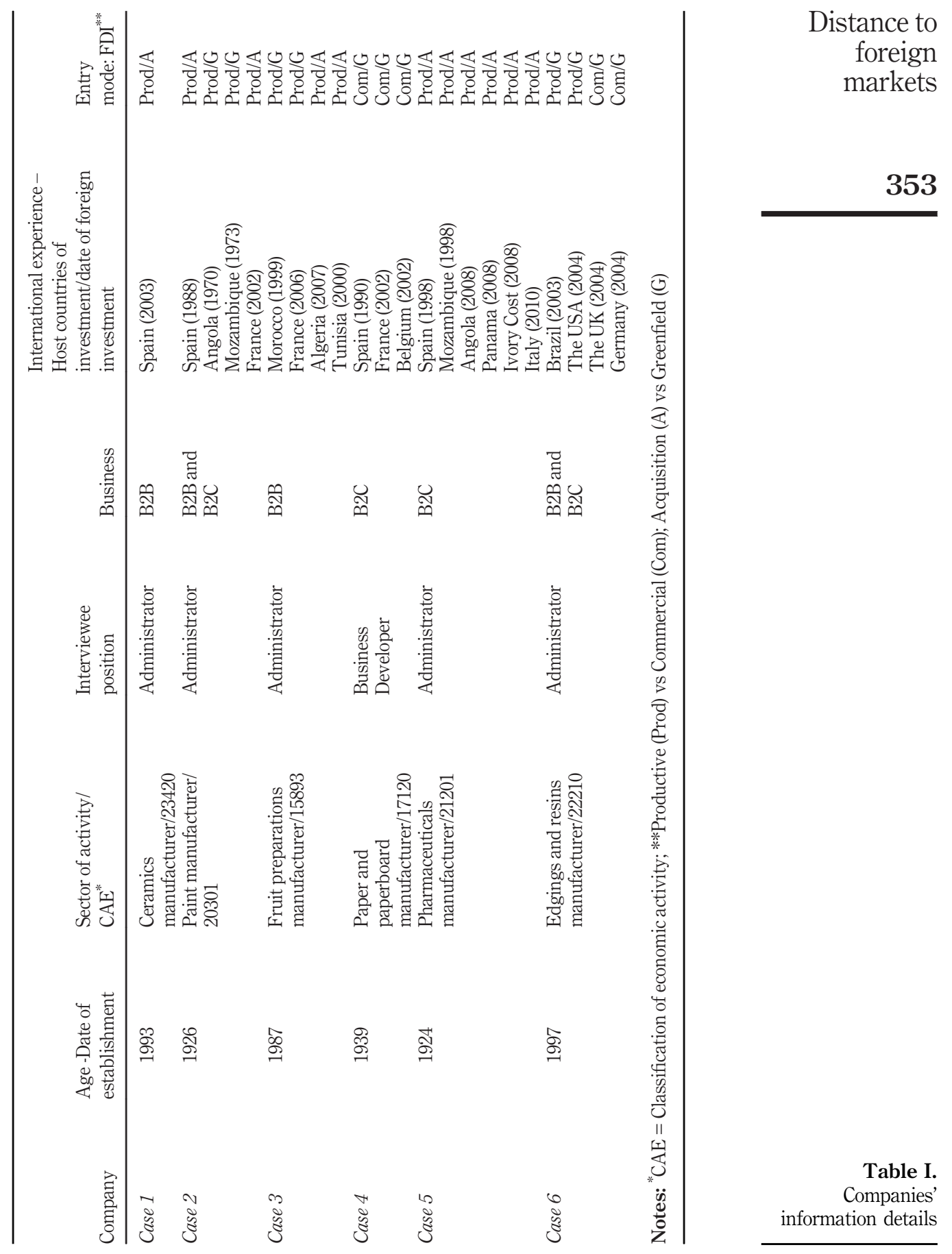


RIBS

29,4

The company named 6 has become a global supplier of thermoplastic edges for the furniture industry because of multi-site production units and accurate competencies in the process that were recognized as standards for quality, innovation and service benchmarks.

The data collection aimed to determine the motivations of the foreign investment and the entire adjustment process to the local market, conditioned by the distance variables of the CAGE model. This information was collected using semi-structured interviews and later supplemented by the collection of company documents between May 2011 and October 2011. The interview had been prepared in a script, but the process was also driven by topics that emerged during each interview and from dealing with unique aspects of each case. The placement of the questions in the interview guide allowed us to assess both the success levels and the performance drivers of each company.

The secondary data were collected from brochures and information released by these companies on their internationalisation processes. According to Yin (2009), the use of multiple data sources to build a case study allows us to consider a more diverse set of topics for analysis while concurrently corroborating the same phenomenon. The respondents held leadership positions in the companies analysed and were involved in decisions about the motivations and process of the parent companies' involvement in the management of the subsidiary. Each interview took, on an average, about three hours and the interviewees were physically present. Before these interviews, information was gathered from secondary sources and by consulting each company's website to increase knowledge about the cases, the characteristics of the company and its internationalisation process. The characteristics of the companies are summarised in Table I, which indicates the business (business to business - B2B, business to consumer - B2C), date and host countries of investment, the nature of FDI (productive/commercial) and the entry mode of FDI (M\&A/greenfield investment).

With respect to the host countries of investment, we found that four companies invested in the neighbouring country, i.e. Spain (Cases 1, 2, 4 and 5) and, except case 1, they also made investments in other countries. The remaining companies did not invest in Spain.

For the entry mode with FDI, we found that four companies selected FDI for acquisition (Cases 1, 2, 3 and 5), while four other companies made greenfield investments (Cases 2, 3, 4 and 6). In two cases (2 and 3 ), both types of entry modes were selected. In most cases, investments were made in the manufacturing sector except for case 6 (which relates both to the manufacturing and service sector) and in case 4 (which is only service-related).

There were two companies that were engaged in the production and sales of industrial and commercial goods (B2B and B2C); two that were engaged in industrial goods only (B2B) and the remaining two were engaged in consumer goods (B2C). The diversity of the sample (by combining different types of direct investment, age, sectors of activity and host countries) favours the emergence and development of theory.

\section{Data analysis procedure}

Using a multiple case design, this research analyses the data in two stages: the first stage was based on the study of each individual case (within-case analysis) that generated reports for each of them. In the second phase, a cross-case analysis led to the elaboration of a comprehensive and final report.

Several methods were used to improve the quality of research. The software N. Vivo allows to manage the data and to help on the extract the business practices of each study unit. The quality was applied using triangulation data with the same interviewer for administering the interviews and different interpretations by three colleagues in the coding of the data, which helped to reduce bias. Theoretical categories were therefore developed 
during open and axial codified procedures. The cases are compared to analyse the similarities and differences to obtain a greater understanding of the processes involved.

Distance to foreign markets

\section{Research findings}

Motivations to invest abroad

In terms of the motivations that led the companies to acquire or establish subsidiaries abroad, we found that three companies referred to market seeking, i.e. the importance of scale (cases 1 and 6), and to extent their range of products (case 2). The remaining companies emphasised asset-strategic motivations, i.e. proximity to the market (cases 3, 4 and 5).

Case testimony:

'[...] It's very difficult to establish business relationships with customers if the company is not located in the destination market' (case 1). '[...] yet it is advantageous to have a physical presence for business' (case 4). 'The need to be in the most important market for this activity, apart from proximity to Portugal in terms of culture, language and legislative framework. '[...] We need to have our own brands in the market of destination' (case 5). '[...] Increase market share, brand awareness because we have an industrial brand, and if we can be together with our customers this improves our reputation' (case 3). '[. . . Maintaining our leadership position in the Iberian market' (case 2). '[...] To increase the market share and brand awareness in order to charge prices equivalent to major competitors' (case 6).

According to Gerschewski et al. (2016), these motivations to be abroad suggests a proactive approach to international markets, which grant the quality of proactiveness to the managers interviewed and a critical value to the success of the international company.

\section{Managers' perceptions of distance dimensions on subsidiary strategy}

The influence of distances between countries on the process of internationalisation of subsidiaries evaluated by the perceptions of headquarters managers provides the answer to the research questions.

\section{Changes caused by cultural distance}

The cultural dimension influenced the strategy of the subsidiary, namely, the kind of organisational culture adopted - as can be seen from some of the quotes from interviewees.

Case testimony:

[. . . T The culture of the subsidiary cannot be changed. [...] What should be the nature of cultural aspects, they have a completely different philosophy to ours'. '[. . . We continue to use the acquired company's brand for products' (case 1). '[...] The company encountered problems on management practices and had to grant more autonomy to subsidiary company' (case 2).

Case testimony:

[...] There were goals that could not be achieved because of 'cultural differences that can be subtle but important' (case 3). Indeed, those differences in values and attitudes that are immersed in the culture forced the company to retire with negative performance.

The practices and behaviours of the host country may be easily integrated into the companies' strategies because companies are aware of them and are willing to implement them because we can observe from the following statements.

Case testimony:

[...] It is a dynamic process; if I want to be competitive, I must look at the offer in those countries and must adapt to the level of services, packaging, in terms of physical and intangible attributes of the product'. '[...] I can produce within the same line, different batches with different raw materials to satisfy the preferences of customers' (case 4). '[...] 
RIBS

29,4

There is a need for different brands according to the destination market' (case 5). '[ . . . We need to realise that who manages the company must understand in which country it is standing and adapt to the culture of this country. For example, in Europe light colours are sold and in US the dark colours are more prevalent' (case 6).

The literature shows that a home country's culture influences the management practises and organisational culture of overseas subsidiaries (Hofstede et al., 1990; Rosenzweig and Nhoria, 1994; Yuen and Hui, 1993). In addition, when headquarters companies establish subsidiaries in foreign countries, they are forced to cope with a multitude of various national cultures.

The interaction between national and organisational culture can potentially lead to tensions. According to Hofstede's national culture framework, Portugal is characterised by a national culture that (compared to others) has high power distance (score $=63$ ), high uncertainty avoidance (score $=104)$, low individualism (score $=27$ ), low masculinity $($ score $=31)$ and long-term orientation $($ score $=30$ ). Deshpandé and Webster $(1989)$ define organisational culture as the pattern of shared values and beliefs that help individuals to understand organisational functioning, thus providing them with the norms for behaviour in the organisation.

National culture could affect organisational culture since, for example, managerial assumptions about employees' nature and behaviour may be influenced by their national culture, i.e. high power distance and uncertainty avoidance at the national level (both of which characterise Portugal's national culture) create low autonomy at the organisational level. In addition, the national cultural dimensions of paternalism, loyalty towards the community and self-reliance influence managers' assumptions about employee reactivity and obligations towards others.

Thus, companies operating in a given context will have organisational cultures that reflect the headquarters company's national cultures; this is also reflected in the level of autonomy they grant. In addition, the cultural values of the host country have a significant effect on the organisational culture of subsidiaries (Hofstede, 1991); thus, different organisational cultures will be developed in the subsidiaries. From the above statements, the following proposition arises:

P1. Cultural distance between countries can dictate an adaptation of the organisational culture in the foreign subsidiary.

\section{Changes caused by administrative distance}

Administrative and legal practices in the host country had relevance with respect to resource allocation to some companies, depending on the country of investment, as can be seen from some of the quotes from interviewees.

Case testimony:

[...] We had some legislative problems, such as the billing' (cases 4 and 5). '[...] In that case we had to make adjustments because credit cards that we used oblige an escrow account. In other country, a law was adopted requiring an import quota and bureaucratisation' (case 3). '[...] We had difficulties in terms of labour contracts, but the greatest problem consists in the repatriation of profits' (case 5).

The administrative distance between countries emphasises the implications of differences in national systems of governance. It covers the overall public institutions and policies that governments create that could inibit or facilitate the business practices.

Research has demonstrated that the subsidiaries of a multinational firm develop a unique set of resources and capabilities because of the different international environments in 
which they operate (Birkinshaw et al., 1998; Ghoshal and Nhoria, 1989). Moreover, using the subsidiary's resources - including physical, technological, knowledge-based, financial, and human resources - is often better determined by foreign subsidiaries because they are more able to identify the particular resources that are needed and to evaluate their ability to deploy them appropriately. In this way, the relationship between the two companies is very critical to business success. Similarly, Kingkaew and Dahms (2018) found that intraorganisational relationship is determinant to increase the headquarter value added and the subsidiary performance.

From the above statements, arises the following proposition:

P2. Administrative distance between countries can dictates an adaptation of resources and legal competencies in the foreign subsidiary.

\section{Changes caused by geographical distance}

Companies take different courses of action to overcome the geographical problem as can be seen from some of the quotes.

Case testimony:

[...] Facing the geographical context, we had to take action to adapt our business model' (case 2).'. . . ] We supply the factory directly from local suppliers. Only in a very few cases we supply raw materials from abroad. (case 3). '[. . . D Due to the physical distance, it can be advantageous for us to store the products during short periods of time' (case 4). '[...] Shipping requires a bigger stock during longer periods than in Portugal.' (case 5).

In fact, transportation costs continue to be a significant element of overall production costs and are likely to deter headquarters' managers from investing in remote countries. For Ghemawat (2001), the geographic distance between countries (besides the physical distance) is associated with communication links and a lack of common border between countries. The international pricing strategy allows headquarters' managers to be able to ensure responsiveness to changing market conditions by building appropriate capabilities.

To deal with the problems of logistics, the companies had to adapt the price of their goods and logistics activities, which resulted in lower than expected performance. From the above statements, arises the following proposition:

P3. Geographical distance between countries requires an adaptation of resources allocation and price of goods in the foreign subsidiary.

\section{Changes caused by economic distance}

Economic differences between countries impose different business strategies as indicated by the interviewees.

Case testimony:

[...] The product we make has to have good reputation and brand image, quality and design because it is a product with great exposure, so we decided to buy the foreign company that had the market but had no product, or qualified human resources' (case 1). '[... The dispersion of consumers' purchasing power has conditioned our business, and we have to change the supply of goods in order to achieve performance' (case 2). '[...] Regarding brand awareness, as we have an industrial brand, when we can be together with our customers, we gain an increase of reputation' (case 3). '[. . . In most of the markets, retail chains are much bigger than companies with the size of our firm. So, we have to change the 
RIBS

29,4

product because of the importance of the scale of our clients and the relationship we develop with them' (case 4).

Countries differ in terms of level of economic development, which has an impact on consumer purchasing power and preferences. Therefore, international companies' managers face the challenge of determining the optimal balance between standardising and adapting their marketing strategies across national borders to be successful (Griffith, 2010; Schmid and Kotulla, 2011).

Consequently, the fundamental decision for headquarters' managers to make is whether to use a standardised marketing mix (product, price, place, promotion, people, physical evidence and process management) with a single marketing strategy in all countries or to adjust the marketing mix to fit the unique dimensions of each potentially unique local market (Vrontis et al., 2006).

As we can observe from the interviews, the economic dimension has direct effects on the company's management about the characteristics, design and brand of the product to meet the needs and demand of the target company, thus increasing customer satisfaction and overall performance. From the above statements, arises the following proposition:

P4. Economic distance between countries requires an adaptation of the characteristics of the product, design and brand in the foreign subsidiary.

\section{Theory testing, theory development and organisational change}

\section{Theory testing}

The transaction cost theory supports that, to overcome their liability of foreignness and to compete successfully against local firms, international firms must provide their overseas subsidiaries with certain firm-specific advantages.

These firm-specific advantages are existing in the companies surveyed. The company named 1 is recognized in the market for its design, quality and excellent brand image; company named 2 said that it will operate in markets where its basic skills are best able to help it achieve a leading position. The company named 3 developed their activity believing that human resources are the most valuable thing. The company named 4 was completely focused on their brand. The company named 5 said that they brought together their knowledge, experience, imagination and dedication to achieve a concrete goal, i.e. providing high quality medicines. Finally, the company named 6 is based in process competencies that are recognized as standards on quality, innovation and service benchmark.

The behaviour theory assumed that entrant firms will initially venture into FDI in foreign markets with lower psychical distance and eventually enter into foreign markets with successively greater psychical distance. In our population of six companies, we verify that four companies invested in the neighbouring country, i.e. Spain. We believe that Spain was chosen as a principal host country of investment due to its geographical proximity to Portugal. The behavioural approach also assumes that knowledge and perceptions change over time during the internationalisation process. The perceptions of the decisor's managers changed during the process of internationalisation, because the differences between the countries that seem with minor geographical distance in case: Spain, is conditioned by the host country. This forced the company to adapt the business practices on their foreign subsidiary and change the managers' perceptions in a way that proximity does not make business abroad easier. Thus, the following proposition is proposed: 
P5. The liability of foreignness to the foreign subsidiary can be greater in neighbouring countries.

\section{Theory development and organisational changes}

The surveyed companies reported that they had to manage their subsidiaries to meet the specific needs of the host country market, which necessitated adjustments to their business practices summarised in Table II.

Companies granted high managerial autonomy to the subsidiary when the entry mode was FDI by acquisition, although there is a sharing of information and knowledge between the parent company and the subsidiary.

Case testimony:

[....] We had to give in and let everything be as it was, not force them to adapt to our management philosophy, which would be a total failure' (case 1). This company had its investment through an acquired company only in Spain. '[...] We had huge difficulties in Spain because we assumed that we were equal, and we did not accommodate the way of doing business of the acquired company' (case 2).

The subsidiary's autonomy can be defined as the rights granted by the parent company in making decisions. A high degree of autonomy occurs when operational decisions and/or strategies are undertaken by the subsidiary (Taggart and Hood, 1999). According to the testimony of the managers of the headquarters, they grant more autonomy to their subsidiaries so that they can more quickly respond to local conditions to solve unexpected problems and properly react to unexpected opportunities. Moreover, Tian and Slocum (2014) studied foreign subsidiaries in China and argued that HQs should grant more autonomy to Chinese subsidiaries to craft strategies that would better respond to indiosyncratic local requirements. Similarly, the study of Alharbi et al. (2016) of multinationals operating in Saudi Arabia show different degree of autonomy considering the country where the subsidiary is operating. The authors report that oriental subsidiaries have comparatively a greater degree of autonomy to subsidiaries from other locations.

\begin{tabular}{|c|c|c|}
\hline Company & $\begin{array}{l}\text { Managers' perception of } \\
\text { distance dimensions with } \\
\text { major impact }\end{array}$ & Organisational changes in the subsidiary strategy \\
\hline Case 1 & $\begin{array}{l}\text { Cultural } \\
\text { Economic }\end{array}$ & $\begin{array}{l}\text { Level of autonomy, product differentiation, design of products, } \\
\text { and brand }\end{array}$ \\
\hline Case 2 & $\begin{array}{l}\text { Cultural } \\
\text { Economic }\end{array}$ & Level of autonomy and product differentiation \\
\hline Case 3 & $\begin{array}{l}\text { Cultural } \\
\text { Administrative } \\
\text { Geographical } \\
\text { Economic }\end{array}$ & Organisational culture, price and product differentiation \\
\hline Case 4 & $\begin{array}{l}\text { Cultural } \\
\text { Administrative } \\
\text { Economic }\end{array}$ & Product differentiation, brand, and price \\
\hline Case 5 & $\begin{array}{l}\text { Cultural } \\
\text { Geographical } \\
\text { Economic }\end{array}$ & Level of autonomy, product differentiation, brand and price \\
\hline Case 6 & $\begin{array}{l}\text { Cultural } \\
\text { Economic }\end{array}$ & Product differentiation, design of products and price \\
\hline
\end{tabular}

Distance to foreign markets 
RIBS

29,4

In the process of investment to the foreign markets, we perceive that the level of autonomy granted to the subsidiary was related to the type of entry mode with FDI, i.e. companies granted high managerial autonomy to the subsidiary when the entry mode with FDI was by acquisition and when the host country was the neighbouring country of the home country. Thus, the following proposition is proposed:

P6. Companies granted high managerial autonomy to the foreign subsidiary when the entry mode with FDI was by acquisition and, the host country was the neighbour of home country.

\section{Conclusions, limitations and future research}

To overcome of the liabilities of foreignness, headquarters' companies choose the strategy that seems to be the most appropriate for the subsidiary in that specific country. In this awareness, there are managers who implement a global integration strategy by offering standardized products in most of their international markets. However, other managers implement a strategy that involves responsiveness to local markets to the extent that they adapt their products and services to the unique local market characteristics.

From the interviewees' reports and comparative analysis of the cases, our results show that the CAGE dimensions of distance influence the strategy of the subsidiary. There is a predominance of economic and cultural dimensions, even within Europe, and smaller impacts of the administrative and geographic dimensions.

Cultural distance leads to adjustments in the organisational culture of the foreign subsidiary, particularly the level of autonomy granted to the subsidiary to meet the environmental specificities of the host country. The administrative distance dictates an adaptation of resources and legal competencies in the foreign subsidiary. Geographical distance between countries require an adaptation of the price of goods in the foreign subsidiary. The economic distance leads to adjustments in the company's offerings, which comprises the characteristics of the product, design and brand.

We also verified that the relationship between parent company and subsidiary - which is conditioned by the national and organisational culture of both companies - will afford a greater degree of autonomy to the subsidiaries that were acquired. We believe that this is a result of the responsiveness of the parent company to the target market; thus, it is proof of a business strategy of adaptation. The headquarter's manager takes in account the particularities of each national market; therefore, the local market-oriented subsidiaries involve a higher degree of flexibility and come down with greater autonomy as was reported by the studies of Martinez and Jarillo (1991) and Harzing (2000).

In addition, and contrary to other studies linked to the incremental internationalisation of the firm as proposed by the Uppsala school (Johanson and Vahlne, 1977; Nordstrom and Vahlne, 1994) when the host country is a neighbour (in this case Spain), the differences seem to be more accentuated.

We believe that Spain was chosen as a principal host country of investment because of its physical proximity to Portugal. However, the headquarters granted high managerial autonomy to the subsidiary when the country was Spain; this fact can be explained by cultural factors. Portugal and Spain belong to two different cultural areas. One is the 'Latin' cluster (Portugal, Italy, Greece and Mexico), and the other is 'Western Europe' (Spain, Germany, France and Switzerland). According to Hofstede (2003), Spain scores on large 'power distance' (57) and an individualist society, while Portugal scores on large power distance (63) and a collectivist society. In high power distance societies, superiors and subordinates feel separated from each other; in other words, real power tends to be very 
much concentrated at the top. The primary difference between these two countries, however, is the strong individualist orientation of Spanish culture, which increases self-reliance and the habit of independently working. This may explain the management and organisational practices with a high level of autonomy for Spanish subsidiaries, at least in terms of the distance between cultures.

The first limitation results from the limited number of cases observed and the small number of countries of investment and industries. Future studies should extend this research to other countries and industries (for instance the services industries) to verify the validity of the findings, because those industries are more culturally sensitive than consumer and industrial goods industries. Other limitation concerns the home country and the entry mode of FDI. The findings presented here reflect the nature and behaviour of Portuguese companies with subsidiaries. Future research should include comparative studies as we can confirm our results in countries with proximity to Portugal such as Spain or even Italy, Greece or Mexico, which belong to the same 'Latin' cluster of countries, as per Hofstede's cultural areas. Finally, longitudinal studies might shed further light on emerging trends related to business distance.

\section{Theoretical and practical implications}

The research results show that multiple distances have an influence on the foreign subsidiary strategy. The propositions reached would help scholars while pursuing future research in foreign subsidiary strategy.

This research provides recommendations for managers to be aware of the influence of more than one dimension of distance between countries to better make their decisions of standardisation-adaptation on foreign markets. The CAGE framework helps managers identify and assess the impact of distance on various industries. Also, managers should consider that proximity does not make business abroad easier.

\section{References}

Alharbi, J., Gelaidan, H., Al-Swidi, A. and Saeed, A. (2016), "Control mechanisms employed between headquarters and subsidiaries in multinational enterprises (MNEs)", Review of International Business and Strategy, Vol. 26 No. 4, pp. 493-516.

Ambos, T.C. and Ambos, B. (2009), "The impact of distance on knowledge transfer effectiveness in multinational corporations", Journal of International Management, Vol. 15 No. 1, pp. 1-14.

Azar, G. (2014), "How congruent are managers'perceptions of cultural distance with objective reality?", Cross Cultural Management: An International Journal, Vol. 21 No. 4, pp. 400-421.

Baack, D.W., Dow, D., Parente, R. and Bacon, D.R. (2015), "Confirmation bias in individual-level

perceptions of psychic distance: an experimental investigation", Journal of International Business Studies, Vol. 46 No. 8, pp. 938-959.

Bartlett, C.A. and Ghoshal, S. (1989), Managing across Borders: The Transnational Solution, Harvard Business School Press, Boston, MA.

Berry, H., Guillén, M.F. and Zhou, N. (2010), “An institutional approach to cross-national distance”, Journal of International Business Studies, Vol. 41 No. 9, pp. 1460-1480.

Birkinshaw, J., Hood, N. and Jonsson, S. (1998), "Building firm-specific advantages in multinational corporations: the role of subsidiary initiative", Strategic Management Journal, Vol. 29, pp. 221-241.

Birkinshaw, J., Brannen, M.Y. and Tung, R.L. (2011), "From a distance and generalizable to up close and grounded: reclaiming a place for qualitative methods in international business", Journal of International Business Studies, Vol. 42 No. 5, pp. 573-581.
Distance to foreign markets 
RIBS

29,4

Buckley, P.J. and Casson, M. (1976), Future of the Multinational Enterprise, Macmillan, London.

Buckley, P.J., Devinney, T.M. and Louviere, J.J. (2007), "Do managers behave the way theory suggests? A choice-theoretic examination of foreign direct investment location decision-making", Journal of International Business Studies, Vol. 38 No. 7, pp. 1069-1094.

Caves, R.E. (1982), Multinational Enterprise and Economic Analysis, Cambridge University Press, Cambridge MA.

Deshpandé, R. and Webster, Jr (1989), "Organizational culture and marketing: defining the research agenda”, Journal of Marketing, Vol. 53 No. 4, pp. 3-15.

Dow, D. and Karunaratna, A. (2006), "Developing a multidimensional instrument to measure psychic distance stimuli”, Journal of International Business Studies, Vol. 37 No. 5, pp. 578-602.

Doz, Y. (2011), "Qualitative research for international business", Journal of International Business Studies, Vol. 42 No. 5, pp. 582-590.

Drogendijk, R. and Slangen, A. (2006), "Hofstede, Schwartz, or managerial perceptions? The effects of different cultural distance measures on establishment mode choices by multinational enterprises", International Business Review, Vol. 15 No. 4, pp. 361-380.

Eisenhardt, K.M. (1989), "Building theories from case study research", Academy of Management Review, Vol. 14 No. 4, pp. 532-550.

Eisenhardt, K.M. and Graebner, M.E. (2007), "Theory building from cases: opportunities and challenges", Academy of Management Journal, Vol. 50 No. 1, pp. 25-32.

Ellis, P.D. (2008), "Does psychic distance moderate the market size-entry sequence relationship?", Journal of International Business Studies, Vol. 39 No. 3, pp. 351-369.

Evans, J. and Mavondo, F. (2002), "Psychic distance and organizational performance: an empirical examination of international retailing operations", Journal of International Business Studies, Vol. 33 No. 3, pp. 515-532.

Gerschewski, S., Lindsay, V. and Rose, E. (2016), “Advancing the entrepreneurial orientation construct: the role of passion and perseverance", Review of International Business and Strategy, Vol. 26 No. 4, pp. 446-471.

Ghemawat, P. (2001), "Distance still matters”, Harvard Business Review, Vol. 79 No. 8, pp. 137-147.

Ghemawat, P. (2007), Redefining Global Strategy - Crossing Borders in a World Where Differences Still Matter, Harvard Business School Press, Boston, MA.

Ghoshal, S. and Bartlett, C.A. (1990), "The multinational corporation as an interorganizational network", Academy of Management Review, Vol. 15 No. 4, pp. 603-625.

Ghoshal, S. and Nhoria, N. (1989), "Internal differentiation within multinational corporations", Strategic Management Journal, Vol. 10 No. 4, pp. 323-337.

Griffith, D.A. (2010), "Understanding multi-level institutional convergence effects on international market segments and global marketing strategy", Journal of World Business, Vol. 45 No. 1, pp. 59-67.

Gulanowski, D., Papadopoulos, N. and Plante, L. (2018), "The role of knowledge in international expansion", Review of International Business and Strategy, Vol. 28 No. 1, pp. 35-60.

Häkanson, L., Ambos, B., Schuster, A. and Deobald, U.-L. (2016), "The psychology of psychic distance: antecedents of asymmetric perceptions", Journal of World Business, Vol. 51, pp. 308-318.

Harzing, A.W.-K. (2000), "An empirical analysis and extension of the Bartlett and Ghoshal typology of multinational companies”, Journal of International Business Studies, Vol. 31 No. 1, pp. 101-120.

Hofstede, G. (1991), Cultures and Organizations: Software of the Mind, McGraw-Hill Book Company (UK) Limited, Berkshire, England.

Hofstede, G. (2003), Culture's Consequences: Comparing Values, Behaviors, Institutions, and Organizations across Nations, 2nd ed., Sage, Thousand Oaks, CA. 
Hofstede, G., Neuijen, B., Ohayv, D. and Sanders, G. (1990), "Measuring organizational cultures", Administrative Science Quarterly, Vol. 35 No. 2, pp. 286-316.

Hutzschenreuter, T., Kleindienst, I. and Lange, S. (2016), "The concept of distance in international business research: a review and research agenda", International Journal of Management Reviews, Vol. 18 No. 2, pp. 160-179.

Hymer, S.H. (1960), The International Operations of National Firms: A Study of Direct Foreign Investment, MIT Press, Cambridge, MA.

Johanson, J. and Vahlne, J.E. (1977), "The internationalization process of the firm: a model of knowledge development and increasing foreign market commitment", Journal of International Business Studies, Vol. 8 No. 1, pp. 23-32.

Johanson, J. and Weidersheim-Paul, F. (1975), "The internationalization of the firm - four Swedish cases", Journal of Management Studies, Vol. 12 No. 3, pp. 305-322.

Kingkaew, S. and Dahms, S. (2018), "Headquarters value added and subsidiary performance: insights from Thailand", Review of International Business and Strategy, Vol. 28 No. 2, pp. 150-168.

Kuo, C.-L. and Fang, W.-C. (2009), "Psychic distance and FDI location choice: empirical examination of Taiwanese firms in China", Asia Pacific Management Review, Vol. 14 No. 1, pp. 85-106.

Maitland, E. and Sammartino, A. (2015), "Managerial cognition and internationalization", Journal of International Business Studies, Vol. 46 No. 7, pp. 733-760.

Martinez, J.I. and Jarillo, J.C. (1991), “Coordination demands of international strategies”, Journal of International Business Studies, Vol. 22 No. 3, pp. 429-444.

Mudambi, R. and Navarra, P. (2002), "Institutions and international business: a theoretical overview", International Business Review, Vol. 11 No. 6, pp. 635-646.

Nordstrom, K.A. and Vahlne, J.-E. (1994), "Is the globe shrinking? Psychic distance and the establishment of Swedish sales subsidiaries during the last 100 years", in Landeck, M. (Ed.), International Trade: Regional and Global Issues, St. Martin's Press, New York, NY, pp. 41-56.

Piekkari, R., Welch, C. and Paavilainen (2009), "The case study as disciplinary convention: evidence from international business journals", Organizational Research Methods, Vol. 12 No. 3, pp. 567-589.

Prahalad, C.K. and Doz, Y.L. (1987), The Multinational Mission: balancing Local Demands and Global Vision, Free Press, New York, NY.

Raziq, M.M., Benito, G.R.G., Toulson, P., Malik, O.F. and Ahmad, M. (2019), "Roles and strategies of foreign MNE subsidiaries in New Zealand", European Journal of International Management, Forthcoming.

Rosenzweig, P. and Nhoria, N. (1994), "Influences on human resource management practices in multinational corporations", Journal of International Business Studies, Vol. 25 No. 2, pp. 229-251.

Rugman, A. and Verbeke, A. (2004), "A perspective on regional and global strategies of multinational enterprises”, Journal of International Business Studies, Vol. 35 No. 1, pp. 3-18.

Schmid, S. and Kotulla, T. (2011), "50 Years of research on international standardization and adaptation - from a systematic literature analysis to a theoretical framework", International Business Review, Vol. 20 No. 5, pp. 491-507.

Taggart, J.H. and Hood, N. (1999), "Determinants of autonomy in multinational corporation subsidiaries", European Management Journal, Vol. 17 No. 2, pp. 226-236.

Tian, X. and Slocum, J.W. (2014), "What determines MNC subsidiary performance? Evidence from China”, Journal of World Business, Vol. 49 No. 3, pp. 421-430.

Vrontis, D., Thrassou, A. and Vignali, C. (2006), "The country-of-origin effect, on the purchase intention of apparel - opportunities and threats for small firms", International Journal of Entrepreneurship and Small Business, Vol. 3 Nos 3/4, pp. 459-476.

Distance to foreign markets 
RIBS

29,4

Wei, Z. and Nguyen, Q.T.K. (2017), "Subsidiary strategy of emerging market multinationals: a home country institutional perspective", International Business Review, Vol. 26 No. 5, pp. 1009-1021.

Yin, R.K. (2009), Case Study Research: Design and Methods, Sage Publications, Los Angeles, CA.

Yuen, E. and Hui, T. (1993), "Headquarters, host-culture and organizational influences on HRM policies and practices", Management International Review, Vol. 33 No. 4, pp. 361-383.

Zaheer, S. and Mosakowski, E. (1997), "The dynamics of the liability of foreignness: a global study of survival in financial services", Strategic Management Journal, Vol. 18 No. 6, pp. 439-464.

\section{About the authors}

Isabel Cristina Martins Antunes is a Professor of Strategic Management at the Porto Accounting and Business School in the Polytechnic Institute of Porto. She received her PhD in Management Sciences in the School of Economics and Management at the University of Porto. She holds her Master's degree in International Business from the University of Minho. Her research interests include international business, strategy management and cross-cultural management. Her current research focuses on international business and international strategic management. Isabel Cristina Martins Antunes is the corresponding author and can be contacted at: isabelantunes@eu.ipp.pt

Hortênsia Gouveia Barandas is a Professor of Marketing and International Business at School of Economics and Management in the University of Porto. She received her $\mathrm{PhD}$ in International Marketing from the University Paris-Dauphine. Her current research focuses on cross-cultural management and branding.

Francisco Vitorino Martins is a Professor of Econometrics at School of Economics and Management in the University of Porto. He received his $\mathrm{PhD}$ in Management Sciences in the University Paris-Dauphine. His current research focuses on quantitative and qualitative methodologies, management and international business.

For instructions on how to order reprints of this article, please visit our website: www.emeraldgrouppublishing.com/licensing/reprints.htm Or contact us for further details: permissions@emeraldinsight.com 